\title{
The Albanian Country, the Institutional and Territory Organisation in the Illyrian Period and during the Principality of "Arbëria"
}

\author{
Ph. D. Irvin Faniko \\ Lecturer University "Hëna e Plotë" Bedër, Tirana, Albania \\ Ph. D. Ervin Karamuço \\ Lecuter University Aleksandër Moisiu, Durrës, Albania
}

\section{Doi:10.5901/mjss.2016.v7n1s1p21}

\begin{abstract}
The purpose of this paper is to give an explanation about the historical development of the states' types established in the territory of Illyria. The methodologies used in this article are the observations in the field of history including also the historic evolution of legal system and its implementation in these states. Albania in antiquity was named Illyria, and bordered to the west by the Adriatic and Ionian Sea, in the north-east of the Alps and the Drava, east of the rivers Danube, Morava and Vardar, south of mainland Greece. Most likely, we are talking about the most ancient civilization residing in the Balkan peninsula, even before the Greeks themselves, even many Illyrian language influences were present in the ancient Greek language. People with Indo-European origin, so preceding Illyrians Helens and were organized in small tribes. Illyrian regime generally ishistoricallyconsidered to be stretched between 1225-165 b.C. Year 1225 b.C., is a hypothetical date and coincides with the year in which historical sources indicate the death of the first Illyrian monarch recognized by us, named the king llius. This paper aims to analyze and provide scientific details on the historical period preceding giving statements on the organization and functioning of Albania at the time.
\end{abstract}

Keywords: state, civilization, principality, population, regulation

\section{The Origin of Albanian Territories}

Most recently is circulating a theory, mostly that prehistory should start from traces of early civilizations encountered in Albanian lands and to be closed in the XIII century BC, at the threshold of the Trojan War when are showed the first signs of the field documentation (Homeric poems) of the Illyrian tribes in their historic homeland (Thëngjilli 2006, p. 9). Illyrians were organized although with tribes, We have data only for these tribes: Abri, Albanoi, Amantini, Andizeti, Arbanitai (Arbani) Ardei (also called Vardaei), Ardian, Arrian, Atitani (Atintani) Autariati, Azali, Breuci, Brigi, Bullioni, Carni, Catari, Celegri, Cerauni, Chelidoni, Colapani, Cornacati, Daesitiati, Delmati, Daorsoi (perhaps Davers-s), Dardan, Dassarsti, Daunii (in central Italy), Deramisti, Deuri, Dindari, Dizioni, Docleti, Enkelei, Enotri (in central Italy), Glintidiones, Grabei, Istria, Iapodi, Jasi, Illiri, Labeali, Lopsi, Mezei, Messapi (in central Italy), Meslcumani, Narensi, Ortoplini, Osseriati, Pannoni, Parentini, Partini, Peresti, Peuceti (in central Italy) Pipusti, Plearei, Sardeati, Scirtari, Scirtoni, Seleitani, Triballi, Taulanti, Vardei perhaps Ardiei speaking Teopompo (Papazoglu 1978, p. 271 onwards) among which were themselves eponymous of Albania: the Albans, they were a highly developed civilization, nay were the first people in Europe who used iron tools. This development allowed them to equip themselves with the best weapons and thus to gain in dealing with neighboring peoples. For this reason, the first being that invaded northern Italy, long before the Celts, and they settled in the region of Veneto and the Adriatic coast.

About the century VI b.C. thanks to the rapid development of economic, agricultural and productive set from metallurgy (for civil and military use) of bronze and iron, developed a strong identity shared by strengthening themselves on the territory by means of trade and in many cases acts of piracy. They established important cities in the Mediterranean coast, among which the city of Durrës, Vlora, Shkodra, Lezha and Butrint. One of the first famous kings was Bardhyli, who reigned in the century IV sec b.C., in the most excellent period, with him Illyria joined Molos (Epirus) but, then, was obliged to join the Celts, to conquer Greece (Sordi 1999, p. 109-116).

However, King Bardhyl(Omari \& Luarasi 2001, p. 10), strong from his previous victories and alliances with Dionysus I of Syracuse, then invaded Epirus and Macedonia killing King Perdika III in 359 b.C., with three thousand soldiers. But Bardhyl didnot organized politically Macedonia and handed to the People's Assembly the election of the new 
king, Philip II of Macedonia, the father of the coming 'Great Alexander'. In the following year, the last defeated the Illyrians of Bardhyl, taking control of their territory till the Lake Ohrid (since 358 b.C.).

Twenty years later, the king Glauk (since 335 b.C.) founded the tribe of Taulants whichis considered as mother family of modern Albania. This tribe is indigenous in areas that lie between the river Vjosë in the south and the city of Epidamos (today Durres) in the north, and is thought to have been created from the mixing of the previous two ethnic groups: Albans and Partans. This tribe settled in the area and stayed at the top of the Illyrian kingdom for the whole Century. III b.C., shifting Enkela.

It was King Glauco that re-won Epidam, in the hands of the Greeks in 312 b.C., Shkodra and Apollonia, reestablishing stability in the kingdom of Illyria. So, he controlled the territories that today are: Albania, Montenegro and Herzegovina. Glauk king's reign was not even a kingdom tyranny and occupation: in fact he was a good ally and this shows that in 309 b.C., he went to Epirus to help Pirro toregain the throne.Glaukit successor was New Bardhyli that, in contrast from his predecessor, was obliged to defend even by Pirro, when the last one occupied territories that were in the south of Shkumbinriver.

The policy of separation from the mainland continued with the successor of Bardhyl, Monunios. He is considered as the first king of real UK Illyrian, after he became mayor of the city Epidamos, chosed as the capital of his kingdom, and celebrated all by cutting silver coins with his portrait and giving in some way a kind of national unity of his kingdom.

After Monounios comes Agron, the famous husband of Queen Teuta, Mrs. of Shkodra, who succeeded after his death in 232 BC. Queen Regent reigned in the role of the son Pine, still a minor, and decided to shift the capital of Illyria in Risan, the city where he died in the presentDalmatia. Queen Teuta was the last queen before the Roman occupation of Illyria. Illyrian people, almost always, indulged in piracy especially in the Adriatic Sea: this enhancement system was supported by the all Illyriankings, though not formally.

\section{The Beginnings of the Roman Empire Conquest in Illyria}

Rome ruled many colonies, almost inthe whole entire coast along Adriatic, and decided to fight openly thellyrian piracy,asking formally Queen Teuta to interupt it. In contrast, Teuta replied to Roman consuls, Caio and Lucio Coruncaino that piracy was not outlawed in the her state, and sent people to kill Lucio Coruncainon because he had not assessed her response. The murder of a Roman ambassador was a very good pretext for Rome to declare war, in this way Rome would reach the double conquest target of Balkan and the elimination of piracy.

In 229 B.C. Roma started the first Illyrianwar (Omari \& Luarasi 2001, p. 16), under the leadership of Fulvio Gneo Centumalo and Postumio Albino: the war took place in the Adriatic Sea with an army of two hundred ships. The first that was captured was Korcira, the actual island of Corfu, moreover thanks to the betrayal of Demetrio of Pharos, a soldier in the service of Teuta sold Romans in exchange for the post of governor of the island.

Roman occupation continued in Epidam, Issas, Apollonia and Shkodra, as far as the Queen was forced to give peace to the Romans. Following the defeat Teuta was forced not to venture with more than two boats in the south of Lezha and to give to Demetrio of Pharos, who had helped the Romans, the bulk of her holdings, thus Epidam, Apollonia, Orikum and Corfu. Moreover, she must pay an annual contribution to Rome, among others, with the release of the Greek cities occupied by Illyrians, in this way attracted the close friendship of Athens.

Invasion of the Roman armyin the century II BC, although brought serious consequences from the military point of view, however, was faced with integration and assimilation policies, thanks to the strong identity of ethnic and cultural origins of the Illyrians. But after the death of Teuta, the hostilities with Rome did not end, once again because of Demetrio of Pharos. In fact he, as he had betrayed Teuta beforein 219 BC, betrayed and Rome, joining at the beginning with the Philip of Macedony and Antigonus III Dosone, that already had taken under protection theheir of Illyrian front, Pinne, still a minor. So, Demetrio, strengthened from the Roman administration and Macedonian protection, began making piracy along the Adriatic coast.

Rome had the pretext for another war Illyrian, in 219 b.C., the consul Lucio Emilio Paolo surrounded the city of Dimal enforcing to surrender, and forced Demetrio to flee to Macedonia. At this time, Illyria became a Roman prefecture.

Illyria became Roman and also the enemy of Macedonia, co-worker betrayal of Demetrios. Rome, moreover was also busy with the Second Punic War and so, after submission, gave more freedom of scope Illyrian dynasties.In fact the century II b.C., the city of his reign King Gent (Omari \& Luarasi 2001, p. 18), Alessio (Lezha current) to make its currency also named "Lisitan". In 180 b.C. Dalmatians were declared independent under the command of King Gent, who put his capital in Shkodra.Romans regained region in $168 \mathrm{BC}$ and the Roman troops in Shkodra caught and sent Gent to Rome in 165 b.C. After a century, Giuglio Cesare and his rival, Pompeo fought their last battle near Durrës.

During the reign of Emperor Tiberio theempire subjugated Illyrian rebel tribes (tribes) of Western Balkan in 9 b.C., 
and it ruled the province of Illyricum, governed by a Roman ambassador. Romans divided the territory in the provinces of Dalmat and Epir. For about four centuries, Roman rule brought in the Illyrian lands a notable commercial and cultural development and ended disputes arising between local tribes. In the mountains of the country, heads of various clans associated retained authority but recognized alliance with the emperor and his delegates authority.

Romans oversaw the construction of water supply and roads, including Egnatia, which linked Dyrrah with Byzantium, and allowed the extraction of: copper, clay and silver extracted from the mountains. For more,the trade flourished more with the export of wine, cheese, olive oil and fish from the Lake of Skadar and Okridës (Ohrid today). On the other hand, Illyricum imported equipment, metal products, luxury goods and other craft items (Biagini 2005, p. 9).

It was in the above period where Apollonia became a cultural center of great importance, as much as Giuglio Cesare himself sent his nephew Cesare Ottaviano (who will later become Emperor Auguso) to take lessons. Then Illyrians were distinguished by the Romans for their skillful fighters who, after being introduced through Roman legions, accounted the biggest part of the Praetorian Guards.Integration of Illyrian-Roman was so great as different Roman emperors were originally from the people of Illyria. Among these is rememberedDioclezian(284-305), Costandin I (324337) and Gustiniano I (527-565) (Anastasi 2002, p. 157-170).

\section{The Roman Empire Fall and the Rule of the Byzantine Empire in Illyria}

With the fall of the Roman empire at the end of the century IV, Illyria came under the rule of the Byzantine Empire and suffered a series of rapid conquests of barbarian people such as Goths and Avars; about century $V$ was the turn of the SlavsMacedonians, who seized the northern part of Illyrian territories. In fact, since 285 throughout the century, lllyria was subordinated by Byzantium. Diocleziani divided Illyria into two regions: Praevalitana, running from the mouth of the Cattaro's and therefore river Shkumbini and involving today's Albania, and Epirus Nova, stretching to the south of the bay of Vlora. Praevalitane Province passed under the Byzantines meanwhile stayed in the West Dalmazia (Margjinaj 1990, p. 20 onwards).

The Byzantine empire exercised a right and limited authority to coastal areas, while inside it suffered influx of Goths, Hungarians, Avars and Slavs (c. IV-th and V AD). It was for this reason that, under Byzantine rule, the development of society suffered a significant slowdown. Moreover, even if Albania belonged to the eastern empire, by clerical it remained dependent on Rome, and this double condition is complicated, not less affiliation with Rome and Byzantium. In mountainous areas Illyrians continued to practice, as in the past, the primitive community relations, while in the lower regions, where the population is mainly engaged in agriculture, began the process of feudalization (Omari \& Luarasi 2001, p. 30).

At the end of the century VI, Praevalitana was again assaulted by barbarian tribes. The Slav Rutomir looted whole villages and became very popular for his persecution against Christians. In 732 the Byzantine emperor Leo of Isauricos, subjected the area under the Constantinople patriarchy. For centuries, the territory of Albania became battlefield of ecclesiastical wars between Rome and Constantinople (Ronchey 2002, p. 10 onwards).

Many Albanians "gegë" living in the north of the river Shkumbin, area that included Tirana today and areas of Shkodra became Catholic while Albanians "toskë" living in the mountainous regions of south-east and in the regions of south-west south Shkumbin converted to Orthodox Church. In 1040, Emperor Basil II managed to re-stabilize rather Byzantine rule. Illyria lost its old name to get theactual one. In 1081, Albania was attacked by the Normans under the leadership of Roberto Guiskardos, but the death of the latter, in 1085, they left the country.

\section{The Begining of Arbëria Principality}

Exactly in this era the feudal relations were significantly expanded. In the III centery the feudal lords solidified their positions and in 1185, were released from the Byzantine control and built their first State: Principality of Arbëria. The main center of this new state was, Krujë and its first sovereign was Progon, (1190-1199) followed by genus. The rest of Albania, the most of its territory was incorporated into the Despotate of Epirus and the kingdom of Sicily.At that time, Albania was still a nation strong and independent, so that in 1261, when Paleologos restored the Western Roman Empire, it was not included and was independent, at least for a decade when in 1271, Carlo Angios founded the kingdom of Albania in territories taken from Despot of Epirus, which reigned under the title 'King of Albania', starting from postsettler. Angioof Naples settled in the new kingdom that stretched from Durrës (their center) to Capo Linguetta.While coastal subdivision was extremely precise, internal borders were not very clear.

Carlo I of Angio dealt more with the coastal area, even ten years later, in 1281, he abandoned those almost without a fight at the inner regions of the Byzantines after a counterattack. These were,inter alia, unfortunate years for Angio, 
agreed in Italy by "Vespri" Sicilian. Precisely because of this weakening angioin Despot of Epirus took the opportunity to re-take a good part of the territories lost by the shrinking kingdom angioine practically only in the region of Dyrrah. However, the city was in the hands of post-Karl's settlers until 1368, when Dyrrah was taken by Karl Topia.

On the day of St. Vitus in 1389, the coalition of the Balkan people (Albanians, Bosnians, Bulgarians, Dalmatians, Serbs and Hungarians) was destroyed in Kosovo's Polje by Pasha Murad I, sultan of the Ottoman Turks, the Pasha's army consisted mainly of Serb militias recruited by Murad I of Macedonia.The day after the battle, fame-harm in Kosovo, three Albanian princes, Balsha, George II and Theodore II of Muzak, led by Gjergj Kastriot, son of Karl Thopia and the grandfather of future Skanderbeg, retreated to their limits and, resisting the Turks were able to set up an Albanian Christian identity stretching from southern borders of Ragusa (Dubrovnik) to the bay of Patras.

Despite the constant attacks of alien invaders (Angioins, Serbs and later Turks), Albania emerged a group of gentlemen, like Topia, Shpata, Balsha, Kastrioti, etc.,who built their feudal principalities and was in constant struggle between them for expanding its rulings. Taking advantage of these disputes and the weakness of the Byzantine Empire during the second half of the XIV century, the State feudal Turks have been increased Osmanlis arrived and began to break through in Albania (loannina), with the intention to invade. With the overthrow of the Albanian people's resistance, they occupied almost the whole country, with the exception of mountain areas and some coastal cities.

\section{Conclusions}

Through this paper we reach the conclusion that the history of the birth and development of the Albanian people in its territories is a story surrounded and characterized by battles of continuous occupation by all neighbors, who in one way or another way have always tried to acquire and establish their autonomy and sovereignty over these lands.

The opposite has been approach by this hospitable and freedom-lovingpeople who aren't subordinated and have tried in all forms and ways to resist foreign occupations, where although conquer they always tried to maintain traditions and indigenous customs.

Another phenomenon is that any invasion of foreigners has left traces in the culture and our traditions, trying way compelling the invasions, which were not only territorial but also an attempt to assimilate Albania in search of new space for perseverance by foreign peoples.

\section{References}

Anastasi A., History of Institutions, the University Publishing House, Tirana 2002.

A. Biagini, Contemporary history of Albania, Tascabili Bompiani, Milano, 2005.

Coal P., History of the Albanian people (395-1831), the Publishing House "Extra", Tirana 2006.

Margjinaj Z., The booklet of the albanian history, compiled in co-operation with Sabattini G., Krinon, Caltanisetta 1990.

Omar L. of Luarasi A., History of State and of law in Albania, Luarasi Publishing House, Tirana 2001.

F. Papazoglou, The Central Balkan current in pre-Roman times: Tribally, autoriatae, dardanians, scordisc and moesians, Hakkert, Amsterdam 1978.

M. Sordi, Two Dionigi, Cletic and Illyrians, at Braccasi Graccioti L., and S. Dalmazia of the other side: problems of adriatic archeology, Olschki LS, Florence in 1999.

Ronchey S., Lo stato byzantine, Mondo Book, Milan 2002. 